DOI: $\underline{10.20472 / E S .2016 .5 .2 .003 ~}$

\title{
RETAIL BANKING IN THE CZECH REPUBLIC - A COMPARISON OF CONSUMER PRICES BETWEEN 2011 AND 2014
}

\author{
ALEŠ ROD, KLÁRA ČERMÁKOVÁ
}

\begin{abstract}
:
The banking sector has been developing very rapidly in the past century. In Czechoslovakia as well as in other post-communist countries, the development differed due to specifics of the centrally planned system with a monobank and no official competition in retail banking. This specific factor influenced the development of the banking industry after 1990, when big banks used information asymmetry in individual parts of profit seeking (esp. income diversification). Growing competition, development of information technology and growing literacy of bank customers have decreased retail prices only after 2011, as shown by performed comparison of retail prices of banking services in the examined period. Using comparison of retail banking clients clusters the paper identifies factors of significant decrease of retail prices of bank services. We focus on discussing these factors, mainly growing competition, growing financial literacy, lowering transaction costs. This paper raises a very important question whether the "big four" on the retail banking market would keep their hegemony or the competition on this market would prevail. To answer this question is the aim of our next research.
\end{abstract}

\section{Keywords:}

Retail banking, competition, financial literacy, income diversification, consumer prices, fees and commissions

JEL Classification: N20, G21, D12

\section{Authors:}

ALEŠ ROD, University of Economics (Department of Economics) , Czech Republic, Email: ales.rod@vse.cz

KLÁRA ČERMÁKOVÁ, University of Economics (Department of Economics) , Czech Republic, Email: klara.cermakova@vse.cz

\section{Citation:}

ALEŠ ROD, KLÁRA ČERMÁKOVÁ (2016). Retail banking in the Czech Republic - a comparison of consumer prices between 2011 and 2014. International Journal of Economic Sciences, Vol. V(2), pp. 42-54., 10.20472/ES.2016.5.2.003 


\section{Introduction}

The economic theory considers the banking sector to be one of the main pillars of product creation as its intermediary function makes allocation of capital more efficient. Sectors as well as banks in individual countries went through an intense development especially in the $20^{\text {th }}$ century and at the turn of the millennium. This was mainly in reaction to or cooperation with three basic processes that are characteristic for this sector - disintermediation, universalisation and diversification of the banking sector. In individual countries these processes differ especially depending on the type of economy, level of regulation or financial literacy on the demand side of banking services (the customer base). In the Czech Republic, just as in other post-communist countries of the Central and Eastern Europe, an abrupt transition to the market principle business, transformation process and activities of consolidation institutions that had a significant impact on the banking sector were specific for these processes ${ }^{1}$. The essence of the banking sector as a field which for a fee (interest margin) provides interconnection of agents with disponible resources and agents demanding these resources because of investment or other plans has basically remained the same since the emergence of first banks. Nevertheless, we can by all means say that the banking sector went through a lot of changes in the second half of the $20^{\text {th }}$ century. These changes were mainly driven by the intensifying regulation of the banking sector, emergence of new non-banking competitors and technological progress. Clients who had no practical experience with competition in the financial services sector became an easy target of embezzlement and financial frauds in the 1990s (the early transformation period). Therefore diversification of financial services towards smaller banks or even outside of the banking sector almost stopped ${ }^{2}$. In 2011 Czech clients of retail banking sector still paid for basic banking services relatively more than it was common in countries of the Western Europe. Development of competition using modern communication tools and modern technologies together with increasing financial literacy made prices in retail banking significantly decline after 2010.

\section{Literature}

In literature with a close focus on the Czech Republic, diversification of banking revenues represents a key part of comparative works that compare trade policies of banks from the retail banking point of view (Matoušek and Taci 2004) or texts that include microeconomic analyses of clients' attitude towards banking fees. For example

\footnotetext{
${ }^{1}$ Read more in Rod (2014).

2 Nevertheless, it was much faster than in less developed Balkan countries, see e.g. Matraku and Gjoka (2014) - in Albania the banking sector is still the most developed sector of the economy and it represents $95 \%$ of the financial sector.
} 
Hedvičáková et al. (2011) describe the role of information asymmetry in retail banking related to banking clients' looking (or not) for better prices for consumption setting of banking products. In another article (Hevičáková et al. 2012) the authors apply Stigler's model adjusted for modelling of information asymmetry of prices in a small banking market. They state that based on their consumption behaviour, more than a half of clients could replace their bank accounts by cheaper ones but they do not do so. The methodology created by Soukal and Hedvičáková (2011) is important for our research. Soukal and Hedvičáková analyse consumption behaviour of banking clients in the Czech Republic and divide them into 5 client groups (clusters). Based on these groups they calculate consumption costs in relation to different kinds of behaviour. Gelos and Roldós (2004) study consolidation processes on emerging banking markets and their influence on the size of the banking sector and profitability of individual entities. Comparative analyses of banking sectors in different countries (e.g. Kášová 1999) also provide stimulating information. As Draessler et al. (2011) say, there is a considerable level of information asymmetry on the Czech banking market with retail banking services, which is caused by the tariff pricing system of banking services (packages). Real prices are therefore composed of market prices and costs on their comparison. These conclusions are consistent with Stigler's findings about information economics (Stigler 1961). Dvořák and Hanousek (2009) analysed determinants of retail banking fees with the use of the index of banking fees. They found that differences between individual fees can be explained by fundamental economic factors as for example the structure of the sector, the level of penetration of cashless economy into the market or differences between banks based on technologies they use and working capital they have.

\section{Analysis}

During the last five years the banking sector in the Czech Republic has undergone important development which significantly changed the situation on the market. Despite the financial crisis the number of banking institution is relatively stable, as can be seen in the table below. ${ }^{3}$ As for the supply side of the banking sector in the Czech Republic, it has mainly changed in the aspect of quality.

\footnotetext{
${ }^{3}$ For example in the USA several hundreds of banking houses and credit institutions have bankrupted since 2007. (Hirby, J. - The Law Dictionary). In the Great Britain 13 banks and saving cooperatives got into serious problems between 2007 and 2008.
} 
Table 1: Banks in the Czech Republic

\begin{tabular}{|c|c|c|c|c|c|c|c|}
\hline & 31.12 .2010 & 31.12 .2011 & 31.12 .2012 & 31.03 .2013 & 30.06 .2013 & 30.09 .2013 & 31.12 .2013 \\
\hline Number of banks as of the date & 41 & 44 & 43 & 44 & 45 & 45 & 44 \\
\hline banks in receivership & 0 & 0 & 0 & 0 & 0 & 0 & 0 \\
\hline $\begin{array}{l}\text { Number of entities created }{ }^{1)} \text { in the } \\
\text { observed period }\end{array}$ & 2 & 3 & 0 & 1 & 1 & 0 & 0 \\
\hline $\begin{array}{l}\text { Number of entities that terminated their } \\
\text { existence }^{2)} \text { in the observed period }\end{array}$ & 0 & 0 & 1 & 0 & 0 & 0 & 1 \\
\hline
\end{tabular}

1) The number of entities "created" includes those that in the observed period received authorization for operation, regardless of whether they actually started to provide services. Based on the type of the entity, authorization for operation means a licence or permit, registration in the Commercial Register or notification of organizational bodies of international entities.

2) The number of entities that "terminated their existence" includes those that in the observed period lost their authorization for operation for any reasons.

Source: Czech National Bank (CNB) - Basic indicators in financial market sectors.

The emergence of new low-cost (low-fee) banks plays a crucial role in this process. Thanks to the use of modern marketing channels these banks offer services for significantly lower prices than already existing banks ${ }^{4}$. In November 2007 mBank (Polish group BRE Bank) entered the Czech and Slovak market. In June 2008 the Czech stock exchange company FIO applied for a banking licence and started to offer retail and corporate banking services. During 2010 the AnaCap Financial Partners group completed acquisition of the Banco Popolare banking house, which was then renamed to Equa Bank and in 2011 started to offer banking services. In July 2011 the first and at that time the only branch of ZUNO Bank (Raiffeisen Bank International) opened as a purely online banking house. Several months later, in November 2011, Air Bank (PPF) appeared on the market.

\section{Table 2: Modelling clusters of banking clients}

\begin{tabular}{|c|c|c|c|c|}
\hline Service/Client's profile & $\begin{array}{l}\text { Active } \\
\text { client }\end{array}$ & $\begin{array}{l}\text { Branch } \\
\text { client }\end{array}$ & $\begin{array}{l}\text { Average on-line } \\
\text { client }\end{array}$ & $\begin{array}{l}\text { Passive online } \\
\text { client }\end{array}$ \\
\hline ATM withdrawal (CZ) & 3,12 & 2,53 & 2,81 & 2,14 \\
\hline ATM withdrawal (CZ) - other banks & 1,02 & 0,37 & 0,77 & 0,41 \\
\hline ATM withdrawal (abroad) & 0,4 & $\mathrm{~N}$ & $\mathrm{~N}$ & $\mathrm{~N}$ \\
\hline ATM withdrawal (abroad) - other banks & 0,41 & $\mathrm{~N}$ & $\mathrm{~N}$ & $\mathrm{~N}$ \\
\hline Incoming payment from another bank & 3,1 & 1,74 & 2,15 & 1,4 \\
\hline Incoming payment from own bank & 2,27 & 0,85 & 0,72 & 0,66 \\
\hline OTP into own bank via branch & 0,11 & 111 & $\mathrm{~N}$ & $\mathrm{~N}$ \\
\hline OTP into own bank via internet & 3,65 & 0,54 & 1,53 & 0,8 \\
\hline OTP into another bank via branch & 0,07 & 1,73 & $\mathrm{~N}$ & $\mathrm{~N}$ \\
\hline OTP into another bank via internet & 4,37 & 0,68 & 4 & 1,28 \\
\hline PP into own bank via branch & 0,03 & 1,59 & $\mathrm{~N}$ & $\mathrm{~N}$ \\
\hline PP into own bank via internet & 2,51 & 0,21 & 0,79 & 0,31 \\
\hline
\end{tabular}

\footnotetext{
${ }^{4}$ Other methods for measuring competition in the banking sector could be used, e.g. Lerner index (Deriantino 2013).
} 


\begin{tabular}{|l|r|r|r|r|} 
PP into another bank via branch & 0,05 & 2,66 & $\mathrm{~N}$ & $\mathrm{~N}$ \\
\hline PP into another bank via internet & 3,05 & 0,26 & 3,03 & 0,57 \\
\hline Direct debit into own bank via branch & 0,03 & 0,77 & $\mathrm{~N}$ & $\mathrm{~N}$ \\
\hline Direct debit into own bank via internet & 1,26 & $\mathrm{~N}$ & $\mathrm{~N}$ & 0,1 \\
\hline $\begin{array}{l}\text { Direct debit into another bank via } \\
\text { branch }\end{array}$ & 0,03 & 1,18 & $\mathrm{~N}$ & $\mathrm{~N}$ \\
\hline $\begin{array}{l}\text { Direct debit into another bank via } \\
\text { internet }\end{array}$ & 1,59 & $\mathrm{~N}$ & $\mathrm{~N}$ & 0,21 \\
\hline Cash deposit via branch & 0,6 & 0,16 & $\mathrm{~N}$ & $\mathrm{~N}$ \\
\hline Cash withdrawal at branch & 0,33 & 0,52 & $\mathrm{~N}$ & $\mathrm{~N}$ \\
\hline Cash back & 0,34 & $\mathrm{~N}$ & $\mathrm{~N}$ \\
\hline
\end{tabular}

$N$... Service is not demanded or the frequency demanded is very low.

OTP... One-time payment.

PP: Permanent payment.

ATM: automatic teller maschine

Source: Soukal and Hedvičáková (2011).

Listing these movements on the banking market is absolutely crucial as these new banks and their different style of marketing and retail communication with clients intensified the pressure on the increase of client mobility and transfer of deposits between individual banks and made existing banks react to this development. Of course, the reaction also concerned bank charges. Soukal and Hedvičáková (2011) define clusters of individual groups of clients which enable observing the trend in charging basic banking services. ${ }^{5}$ Based on the analysis of more than 8000 respondents' consumption behaviour in relation to retail banking, four clusters were created. Each cluster is a characterization of a type of clients. Clients' behaviour was modelled with the use of bank charges of individual banks that are currently effective (Tab. 11). The authors expect the individual client types to represent the following percentage of the total client base ${ }^{6}$ :

- $\quad$ Active client: $16.3 \%$

- $\quad$ Average client preferring branches: $8.3 \%$

- $\quad$ Average client: $39 \%$

- $\quad$ Passive client: $35.9 \%$

Outputs of the methodology can be used for demonstration of price effects that new banks introduced to the Czech banking sector. Because of the emergence of new

\footnotetext{
5 The authors called the methodology banking index.

${ }^{6}$ More information about the methodology is available for example here: http://www.bankovnipoplatky.com/bankovni-index---metodika-12509.html
} 
banks at the market, the year 2011 can be called the key year for the change at the supply side of the Czech banking sector. Let us therefore compare outputs of the Banking Index, which is a comparison of the costs of individual client profiles, created by Soukal and Hedvičíková (2011) from the first quarter of 2011 (prior to the emergence of new institutions at the market) and from the first quarter of 2014 (after the emergence of new institutions at the market and changes of the banking sector). The Table 12 provides a list of fifteen most favourable (least expensive) product packages in the form of bank accounts for individual client profiles (Active Client; Branch Client; Active Internet; Passive Internet), which reflect the price policy of bank charges in the Czech Republic in 2011. The Table 13 is organized in the same way and describes fifteen most favourable offers for the four model client profiles (Active Client; Branch Client; Active Internet; Passive Internet). This table takes into account information about bank charges of Czech banks that were effective in the first quarter of 2014.

There is only one difference between the two data sets and that is the four year time interval. Other characteristic features of the two sets are completely identical.

Table 3: Fifteen most favourable accounts for the client profiles (1 ${ }^{\text {st }}$ quarter of 2011, costs of the client in CZK per month)

\begin{tabular}{|c|c|c|c|}
\hline Active Clients & Costs in CZK & Branch Clients & Costs in CZK \\
\hline Fio current account ${ }^{* *}$ & 143 & Banco Popolare current account & 156 \\
\hline LBBW 5 for 50 account $^{* *}$ & 200 & Banco Popolare On-line account & 156 \\
\hline UniCreditBank Partners account & 211 & Banco Popolare Prima account & 160 \\
\hline UniCredit Mozaika account & 223 & PS Era Personal Account & 185 \\
\hline PS Era Personal Account & 225 & LBBW IQ account FREE OF CHARGE & 190 \\
\hline PS Personal account & 225 & LBBW 5 for 50 Account & 209 \\
\hline LBBW IQ account FREE OF CHARGE & 229 & Raiffeisenbank eAccount Extra* & 228 \\
\hline ČSOB ACTIVE ACCOUNT I & 234 & Volksbank STYL account & 236 \\
\hline Volksbank STYL account & 235 & Volksbank Current & 257 \\
\hline Volksbank Current & 256 & Volksbank FIT account & 261 \\
\hline Volksbank FIT account & 260 & KB Extra account & 269 \\
\hline KB Extra account & 264 & Banco Popolare Grande account & 273 \\
\hline UniCredit Account Complet & 267 & ČSOB ACTIVE ACCOUNT & 293 \\
\hline GE Money GENIUS ACTIVE & 276 & ČSOB CURRENT & 314 \\
\hline ČSOB CURRENT I & 298 & Raiffeisenbank eAccount Basic & 314 \\
\hline Average Internet Client & Costs in CZK & Passive Internet Client & Costs in CZK \\
\hline mBank mACCOUNT ${ }^{* * *}$ & 32 & mBank mACCOUNT*** & 23 \\
\hline Fio current & 65 & Fio current & 50 \\
\hline PS Personal Account Free of Charge & 72 & PS Personal Account Free of Charge & 58 \\
\hline Raiffeisenbank eAccount Extra* & 105 & Raiffeisenbank eAccount Extra* & 60 \\
\hline
\end{tabular}




\begin{tabular}{|c|c|c|c|}
\hline LBBW 5 for 50 Account & 118 & Banco Popolare current & 82 \\
\hline PS Personal Account Era & 122 & Banco Popolare On-line account & 82 \\
\hline ČSOB ACTIVE ACCOUNT & 125 & LBBW IQ account FREE OF CHARGE & 84 \\
\hline LBBW IQ account FREE OF CHARGE & 127 & Banco Popolare Prima account & 86 \\
\hline Banco Popolare current & 131 & PS Personal Account Era & 95 \\
\hline Banco Popolare On-line account & 131 & LBBW 5 for 50 Account & 97 \\
\hline Banco Popolare Prima account & 135 & ČSOB ACTIVE ACCOUNT & 105 \\
\hline UniCredit Account Mozaika & 144 & KB IDEAL account ${ }^{* * *}$ & 110 \\
\hline Volksbank STYL account & 149 & ČSOB CURRENT & 113 \\
\hline KB Extra account & 152 & ČSOB ACCOUNT & 113 \\
\hline UniCreditBank Partners account & 156 & Volksbank STYL account & 115 \\
\hline
\end{tabular}

* on the condition that the client reaches a certain turnover or average monthly balance

** the cash-back service is not available for this account

${ }^{* * *}$ no condition related to the turnover on a debit or credit card

**** on the condition that the client pays by card more times than he withdraws money from the ATM

Source of data: www.bankovnipoplatky.com

Table 4: Fifteen most favourable accounts for the client profiles (1st quarter of 2014, costs of the client in CZK per month)

\begin{tabular}{|c|c|c|c|}
\hline Active Client & $\begin{array}{l}\text { Costs in } \\
\text { CZK }\end{array}$ & Branch Client & $\begin{array}{l}\text { Costs in } \\
\text { CZK }\end{array}$ \\
\hline Equa bank current ${ }^{* *}$ & 0 & Equa bank current** & 0 \\
\hline GE Money Bank Genius Gold Account* & 0 & GE Money Bank Genius Gold Account* & 0 \\
\hline Fio banka Fio current & 10 & Equa bank Equa bank current & 99 \\
\hline GE Money Bank Genius Active Account* & 69 & GE Money Bank Genius Active Account ${ }^{\star}$ & 188 \\
\hline ČSOB Exclusive account* & 82 & GE Money Bank Genius Gold Account** & 199 \\
\hline Equa bank Equa bank current & 99 & $\begin{array}{l}\text { Komerční banka KB My Account with a 100\% } \\
\text { bonus }\end{array}$ & 202 \\
\hline Sberbank Sberbank Fair Account Start Option & 134 & $\begin{array}{l}\text { Raiffeisenbank Raiffeisenbank eAccount } \\
\text { Premium }{ }^{\star *}\end{array}$ & 223 \\
\hline $\begin{array}{l}\text { Raiffeisenbank Raiffeisenbank eAccount } \\
\text { Complet }^{\star *}\end{array}$ & 138 & ČSOB ČSOB EXCLUSIVE ACCOUNT** & 224 \\
\hline $\begin{array}{l}\text { Raiffeisenbank Raiffeisenbank eAccount } \\
\text { Premium** }\end{array}$ & 141 & $\begin{array}{l}\text { Komerční banka KB My Account with a 50\% } \\
\text { bonus }\end{array}$ & 236 \\
\hline Sberbank Sberbank Fair Account Plus Option & 145 & Česká spořitelna personal account II & 243 \\
\hline $\begin{array}{l}\text { Komerční banka KB My Account with a } 100 \% \\
\text { bonus }\end{array}$ & 161 & Komerční banka KB My Account & 270 \\
\hline Poštovní spořitelna PS Online account* & 163 & Fio banka Fio current & 271 \\
\hline Sberbank Sberbank Fair Account Extra Option & 164 & $\begin{array}{l}\text { Raiffeisenbank Raiffeisenbank eAccount Complet } \\
\text { ** }\end{array}$ & 271 \\
\hline ČsOB Active Account & 177 & Poštovní spořitelna PS Era Personal Account & 297 \\
\hline Česká spořitelna Personal Account II & 282 & LBBW LBBW 5 for 50 Account & 298 \\
\hline Average Internet Client & $\begin{array}{l}\text { Costs in } \\
\text { CZK }\end{array}$ & Passive Internet Client & $\begin{array}{l}\text { Costs in } \\
\text { CZK }\end{array}$ \\
\hline Citibank Citiaccount Plus* & 0 & Citibank Citiaccount Plus* & 0 \\
\hline Citibank Citiaccount Plus ${ }^{* *}$ & 0 & Citibank Citiaccount Plus ${ }^{* *}$ & 0 \\
\hline Equa bank current ${ }^{* *}$ & 0 & Equa bank Equa bank current ** & 0 \\
\hline
\end{tabular}




\begin{tabular}{|c|c|c|c|}
\hline Fio banka Fio current & 0 & Fio banka Fio current & 0 \\
\hline GE Money Bank Genius Gold Account* & 0 & GE Money Bank Genius Gold Account* & 0 \\
\hline mBank mACCOUNT ${ }^{\star \star *}$ & 0 & mBank mBank mACCOUNT & 0 \\
\hline $\begin{array}{l}\text { UniCreditBank UniCreditBank Partners (Active) } \\
\text { account free of charge }\end{array}$ & 0 & $\begin{array}{l}\text { UniCreditBank UniCredit Account Perfect free of } \\
\text { charge }\end{array}$ & 0 \\
\hline $\begin{array}{l}\text { UniCreditBank UniCredit Account Perfect free of } \\
\text { charge }\end{array}$ & 0 & $\begin{array}{l}\text { UniCreditBank UniCreditBank Partners (Active) } \\
\text { account free of charge }\end{array}$ & 0 \\
\hline ZUNO ZUNO Plus account ${ }^{\star \star \star \star *}$ & 0 & Airbank Airbank Small Tariff & 0 \\
\hline ZUNO ZUNO Plus account * & 0 & ZUNO ZUNO Plus account * & 0 \\
\hline Airbank Airbank Small Tariff & 19 & ZUNO ZUNO Plus account ***** & 0 \\
\hline GE Money Bank Konto Genius Active * & 30 & Airbank Airbank Small Tariff & 10 \\
\hline ČSOB ČSOB EXCLUSIVE ACCOUNT* & 38 & ČSOB ČSOB EXCLUSIVE ACCOUNT * & 16 \\
\hline Poštovní spořitelna PS Online account* & 72 & GE Money Bank Genius Active Account* & 16 \\
\hline Citibank CITI- account & 86 & Citibank CITI- account & 26 \\
\hline
\end{tabular}

* with the balance required

** with the turnover required

*** when paying by card as much as required

**** on the condition that the client pays by card more times than he withdraws money from the ATM

Source of the data: www.bankovnipoplatky.com

Comparison of the two data sets from 2011 and 2014 has brought very interesting results for all the client clusters. The Table 14 shows that quantitative features of the fifteen best accounts for retail bank clients have significantly changed. In 2011 the model case Active Client could not get a bank account for less than $143 \mathrm{CZK}$, even though all conditions set by the bank were met (most often it was the turnover or the minimum balance on the bank account). In 2014 nine banks made it possible and two of them offered accounts completely free of charge. Both the average value and the median value significantly changed during the two observed periods - they decreased dramatically. The higher standard deviation in 2014 shows that price offers of the fifteen cheapest accounts for the Active Client cluster fall within a broader range of values.

Table 5: Cluster "Active Client" in 2011 and 2014

\begin{tabular}{|l|c|c|}
\hline ACTIVE CLIENT & $\mathbf{1}^{\text {st }}$ quarter of 2011 & $\mathbf{1}^{\text {st }}$ quarter of $\mathbf{2 0 1 4}$ \\
\hline N_best & 15 & 15 \\
\hline Minimum & 143 & 0 \\
\hline Maximum & 298 & 282 \\
\hline Average & 236.40 & 117.67 \\
\hline Median & 234 & 138 \\
\hline Standard deviation & 35.77 & 73.87 \\
\hline
\end{tabular}

Source: Our own calculations. 
Results obtained in the Table 15 for the Branch Client cluster and the fifteen offers of bank accounts that are the best for this model of consumption behaviour can be interpreted in a similar way. The lowest monthly amount of money decreased from 156 CZK to $0 \mathrm{CZK}$. Services free of charge were offered by two banks.

Table 6: Cluster "Branch Client” in 2011 and 2014

\begin{tabular}{|l|c|c|}
\hline BRANCH CLIENT & $\mathbf{1}^{\text {st }}$ quarter of 2011 & $\mathbf{1}^{\text {st }}$ quarter of 2014 \\
\hline N_best & 15 & 15 \\
\hline Minimum & 156 & 0 \\
\hline Maximum & 314 & 298 \\
\hline Average & 233.40 & 201.40 \\
\hline Median & 236 & 224 \\
\hline Standard deviation & 53.49 & 92.58 \\
\hline
\end{tabular}

Source: Our own calculations.

Due to operational costs, transactions carried out at a place of business are subject to higher charges than transactions that are carried out through other sales channels. However, the average decreased by $13.7 \%$ and the median decreased by $5.1 \%$. If clients were willing to switch to one of the two best options, they could considerably cut down their expenses and therefore the segment changes can be described as significant.

The offer for the Active Internet Client cluster has probably gone through the greatest change. While in 2011 clients who used mainly the Internet banking to manage their accounts could get the services for 32 CZK a month, in the first quarter of 2014 there were seven banking houses that provided altogether 10 accounts with these services for free. The maximum value in the offer of the 15 best consumer options fell by almost a half to $86 \mathrm{CZK}$ per month. The average decreased by $86 \%$ to $16.33 \mathrm{CZK}$ per month. The median value of the set in the $1^{\text {st }}$ quarter of 2014 fell to $0 \mathrm{CZK}$. The standard deviation decreased too, in contrast to the previous two clusters. Positive price changes in this client segment took place throughout the whole observed set.

Table 7: Cluster "Active Internet Client" in 2011 and 2014

\begin{tabular}{|l|c|c|}
\hline ACTIVE INTERNET CLIENT & $\mathbf{1}^{\text {st }}$ quarter of $\mathbf{2 0 1 1}$ & $\mathbf{1}^{\text {st }}$ quarter of $\mathbf{2 0 1 4}$ \\
\hline N_best & 15 & 15 \\
\hline Minimum & 32 & 0 \\
\hline Maximum & 156 & 86 \\
\hline Average & 117.60 & 16.33 \\
\hline Median & 127 & 0 \\
\hline Standard deviation & 34.15 & 27.43 \\
\hline
\end{tabular}

Source: Our own calculations. 
Costs of the consumer behaviour of the Passive Internet Client group also went through a change between the $1^{\text {st }}$ quarter of 2011 and the $1^{\text {st }}$ quarter of 2014. In 2011 the minimum costs among the 15 best offers were 23 CZK per month and the maximum value was $115 \mathrm{CZK}$ per month. The average and the median were very similar (the average was $84.87 \mathrm{CZK}$ per month and the median was $86 \mathrm{CZK}$ per month). In 2014 there were eleven options for receiving services free of charge and the maximum value was $26 \mathrm{CZK}$ per month. The average value was $4.53 \mathrm{CZK}$ per month and the median value was $0 \mathrm{CZK}$. This represents a substantial change of the banking market. In this customer segment the standard deviation significantly decreased as well (8.08).

Table 8: Cluster "Passive Internet Client" in 2011 and 2014

\begin{tabular}{|l|c|c|}
\hline PASSIVE INTERNET CLIENT & $\mathbf{1}^{\text {st }}$ quarter of 2011 & $\mathbf{1}^{\text {st }}$ quarter of 2014 \\
\hline N_best & 15 & 15 \\
\hline Minimum & 23 & 0 \\
\hline Maximum & 115 & 26 \\
\hline Average & 84.87 & 4.53 \\
\hline Median & 86 & 0 \\
\hline Standard deviation & 26.05 & 8.08 \\
\hline
\end{tabular}

Source: Our own calculations.

\section{Results and implications}

In relation to both the compared data sets and all four client segments we can say that product offers of big banks (Česká spořitelna, Československá obchodní banka, Komerční banka) are not very much represented in the interval of the fifteen most favourable offers. Despite the economy of scale and other economic features, these banks can be seen as relatively expensive. However, the position of big banks is still relatively strong in the Czech Republic. In 2014 there were over forty banks and branches of international banks and three biggest banks managed $51.43 \%$ of the total assets of the Czech banking sector. In our opinion the decrease of prices was really caused by the emergence of banks with low charges as well as by other factors: financial innovations (see Janicko 2015), mobility of clients and client initiatives.

The issue of (un)stable dominance of big banks in the banking sector of a country is closely related to willingness to switch banks, that is client mobility. The factor of mobility of bank clients has been forming the banking market in the Czech Republic (especially the retail one) only in the last few years. Consumers' willingness to change 
their bank is relatively higher and that is caused by greater awareness, increasing competition and also activity of the professional organization called Czech Banking Association. This organization has promoted client mobility among its member banks by a project called the Code of Banking Mobility of the Czech Banking Association Banking Clients that makes switching banks easier. ${ }^{7}$ However, despite its practical benefits, clients are little aware of the Code of Mobility. ${ }^{8}$

The current competitive environment of the Czech banking sector is also shaped by client initiatives with a narrow focus. There is a client survey called The Most Absurd Bank Fee, which is a client survey popularizing the issue of price policy in retail banking sector and it receives a lot of media coverage. ${ }^{9}$ The survey has been taking place every year since 2005 and there are three rounds of online voting (nomination $-1^{\text {st }}$ round - final round). In the past years clients described the following fees as the most absurd: fee for an incoming payment (2005), fee for a withdrawal from one's own bank's ATM (2006), fee for maintaining a current account (2007), fee for an excessive deposit (2008), fee for a deposit on one's own account at the counter (2009), fee for a withdrawal from one's own account at the counter (2010), fee for an early repayment of a credit (2011), fee for balance inquiry via an ATM (2012), fee for maintaining a credit account (2013), fee for an account statement sent electronically (2014).

There are several ways to prove that this initiative has an impact on the sector. Every year after the survey some banks regularly decide to remove the "most absurd" fees from their schedule. They also inform their current and potential clients about this change. ${ }^{10}$ Banking houses also use the "most absurd" fees - or rather their absence in their schedules - as a marketing tool. ${ }^{11}$ Relevance of the aforementioned circumstances is also confirmed by a recent survey on banking clients' behaviour in

\footnotetext{
7 Shortened as Code of Mobility. This document signed by all CBA members is a multilateral convention, which allows clients to change banks by signing a special form in the new target bank. Banks have agreed that in these cases they will constructively cooperate and that the first bank will help the target bank to settle agreements, terminate the products associated with the ownership of the original current account and transfer deposits as well as direct debits, permanent payment orders and other information to the new bank. More information is available here: https://www.czech-ba.cz/cs/aktivity/kodex-mobility-klientu.

8 The only survey related to this topic the author is aware of was carried out at the beginning of 2011, when readers of the www.bankovnipoplatky.com Internet portal were asked: "Do you know what the Code of Banking Clients Mobility is?" The survey lasted for two weeks and 77 percent of the total number of 497 respondents answered "I have no idea what it is," despite the fact that this portal has a separate section for this issue and regularly publishes articles related to it.

${ }_{9}$ See here: http://www.bankovnipoplatky.com/ankety/nejabsurdnejsi-bankovni-poplatek.html.

10 For example here: http://www.bankovnipoplatky.com/poplatek-za-vklad-hotovosti--nejprve-nejabsurdnejsi-pakzrusen-zakonem-14783.html. The most absurd fee of 2013 also started a discussion on the legality of a fee for maintaining a credit account, initiated by the Poplatkyzpet.cz initiative based on the finding of the Constitutional Court. Eight banking houses abolished the fee for some or all their credit products during the dispute (as of the $23^{\text {rd }}$ of June 2013) and another two followed later. More information available here: http://www.bankovnipoplatky.com/poplatek-za-vedeni-uveroveho-uctu-banky-ho-haji-ale-zaroven-rusi-19867.

11 For example here: http://www.bankovnipoplatky.com/prvni-reakce-na-nejabsurdnejsi-poplatek-prisla-zraiffeisenbank-10446.html, or here: http://www.novinky.cz/finance/280673-banky-stale-casteji-poskytuji-pujcky-ibez-poplatku.html.
} 
the European Union countries (EY 2014). It shows that as for the issue of charges, banking clients in the Czech Republic are now the second most sensitive group in Europe $-47 \%$ of clients in the CR have cancelled a product in their bank because of the price policy (in Ireland it was 60\%; the average of the EU is $36 \%$ ). According to surveys, $51 \%$ of clients in the CR say that they associate trust in a banking house with the issue of bank fees. $50 \%$ of clients that have concluded contracts on products with more than one bank decided to do so to reach lower charges or more favourable interest rates - higher for savings accounts and lower for credit accounts.

\section{References}

BANKOVNIPOPLATKY.COM. Nejabsurdnější bankovní poplatek. On-line, link: http://bit.ly/VmGqjd.

BANKOVNIPOPLATKY.COM. Poplatek za vedení úvěrového účtu? Banky ho hájí, ale zároveň ruší. On-line, link: http://bit.ly/VBIOm7.

BANKOVNIPOPLATKY.COM. Poplatek za vklad hotovosti - nejprve nejabsurdnější, pak zrušen zákonem. On-line, link: http://bit.ly/1l6f8tw.

BANKOVNIPOPLATKY.COM. První reakce na nejabsurdnější poplatek priš̌la z Raiffeisenbank. On-line, link: http://bit.ly/1uQXLjF.

ČESKÁ BANKOVNÍ ASOCIACE. Kodex mobility klientů. On-line, link: http://bit.ly/1t2XmHA.

ČESKÁ NÁRODNÍ BANKA. Základní ukazatele o sektorech finančního trhu. On-line, link: http://bit.ly/1EjnYOr

DERIANTINO, E., 2013. Banking Competition and Effectiveness of Monetary Policy Transmission: A Theoretical and Empirical Assessment on Indonesia case, International Journal of Economic Sciences, 2(3), 21-35.

DRAESSLER, J., SOUKAL, I. and HEDVIČÁKOVÁ, M. 2011. Shluková analýza poptávkové strany trhu základních bankovních služeb, E+ M Ekonomie a Management, 11(4).

DVOŘÁK, P. and HANOUSEK, J., 2009. Paying for Banking Services: What Determines the Fees?. Praha: CERGE-EI Working Paper Series, č. 388.

ERNST \&YOUNG, 2014. Global Consumer Banking Survey 2014. On-line, link: http://bit.ly/1yUjvc0.

GELOS, R. G. and ROLDÓS, J., 2004. Consolidation and market structure in emerging market banking systems, Emerging Markets Review, 5(1), 39-59.

HEDVIČÁKOVÁ, M., SOUKAL, I. and DRAESSLER, J., 2011. Retail Core Banking Services Information Asymmetry Case Study Using the Small Market Model Adjustment. RECENT RESEARCHES in ECONOMICS, Proceedings of the $2^{\text {nd }}$ International Conference on Finance and Accounting (ICFA'11), Montreux, Switzerland.

HEDVIČÁKOVÁ, M., SOUKAL, I. and DRAESSLER, J., 2012. Probabilistic model of optimal price search on the retail core banking services market. International Journal of Mathematical Models and Methods in Applied Sciences, 386-393.

JANÍČKO, M., 2015. Mainstream Versus Heterodox View on Financial Innovation. International Journal of Economic Sciences, 6(1), 1-24. 
KÁŠOVÁ, K., 1999. Srovnání bankovního sektoru v ČR a Rakousku ve 2. pol. 90. let, Czech Journal of Economics and Finance, 6, 367-387.

MATOUŠEK, R. and TACI, A., 2004. Efficiency in banking: empirical evidence from the Czech Republic, Economics of Planning, 37(3-4), 225-244.

MATRAKU, D. and GJOKA, E., 2014. Competition in Albanian banking sector, International Journal of Business and Management, 2(1), 18-28.

NOVINKY.CZ. Banky stále častěji poskytuji půjčky i bez poplatku. On-line, link: http://bit.ly/1BwH2Up.

POPLATKYZPET.CZ. O projektu a jeho garantech. On-line, link: http://bit.ly/VCbGL3.

ROD, A., 2014. Development, legislative framework and goals of the consolidation institutions in the Czechoslovakia and the Czech Republic, International Journal of Social Sciences, 3(4), 107-123.

SOUKAL, I. and HEDVIČÁKOVÁ, M., 2011. Retail core banking services e-banking client cluster identification, Procedia Computer Science, 3, 1205-1210.

STIGLER, G. J. 1961. The economics of information, The journal of political economy, 69(3), 213-225.

ÚSTAVNÍ SOUD. 2014. Nález Ústavního soudu ČR č.j. III. ÚS 3725/13. On-line, link: http://bit.ly/1ikARdg. 